\title{
Transport Network Analysis: A Case Study on Upper Assam District of Assam
}

\author{
Neelakshi Borthakur
}

\begin{abstract}
This paper is totally based on a critical review of Transport Network Analysis in a Upper Assam district of State of Assam in India. It's a comparative study between ASTC Bus Services and Traveller Services from Jorhat District (Centre) to Tinsukia, Dibrugarh, Sibsagarh, Golaghat, Lakhimpur and Dhemaji District. There have only 11 ASTC Bus Services and More than (on Average) 15 Traveler Service in every district. The ASTC Bus Services were fixed for riding every day but Traveller Services are not fixed. It is flexible on time and demand by the passengers situations. From these it is clear that the government (ASTC) bus service are very less than the traveler services in this Upper Assam. There have many factors for the shortage of Govt. service and increase of Traveller Services. For this there have face many problems by passenger like travel fare, capacity of arrangement of seats, lack of comfortness of travelling etc.

Keywords: Transport Network ; Upper Assam; Factors ; Problem and Future.
\end{abstract}

\section{INTRODUCTION}

Transport Network Analysis is concerned primarily with the spatial or temporal nature of the movement of people and freight across land where the movement channeled onto roads or railways. Thus, it is a connecting line between two places in any mode of transports. The term "Network" refers to the framework of routes within a system of locations identified as nodes. A route is a single link between two nodes that are part of a larger network that can refer to tangible routes such as roads and rails or less tangible routes such as air and sea corridors.

The National Highway in India are a network of trunk roads which is owned by the Ministry of Road Transport and Highways. It is constructed and managed by the National Highway Authority of India, the National Highways and infrastructure development corporation and the public works department of state government. India has 142,126 km of National Highways as of April 2019. In Upper Assam, there have many katcha and pakka road. There have total length of $3900.44 \mathrm{~km}$ national highway in Assam. There are 39 National Highways running through Assam . But NH 37, NH 38, NH 52 can be seen in Upper Assam.

Revised Manuscript Received on April 15, 2020.

* Correspondence Author

Neelakshi Borthakur*, Assistant Professor, Department of Geography, D.C.B Girls' College Jorhat, Assam, India. Email: neelakshi016@gmail.com

(c) The Authors. Published by Blue Eyes Intelligence Engineering and BY-NC-ND license (http://creativecommons.org/licenses/by-nc-nd/4.0/) Sciences Publication (BEIESP). This is an open access article under the CC

\section{OBJECTIVE}

(a) To study a comparative analysis between ASTC Bus Service and Traveller Services

(b) To study about the factors and problems faces by the passenger in this areas.

(c) To deals with the present and future services in both the service

\section{DATA AND METHODOLOGY}

For this paper, both Primary and Secondary data should be used. Primary data were collected from research questions, interview and personal observation. Secondary data are collected from books, journal, internet etc. In this paper, descriptive, functional, analytical and action research method can be used.

\section{STUDY AREA}

Upper Assam is a one of the Part of State of Assam in India. It comprises of seven districts. They are Tinsukia, Dibrugarh, Sivsagar, Jorhat, Golaghat, Lakhimpur and Dhemaji (2011 census). It is located in Arunachal Pradesh in the North; Arunachal Pradesh and Nagaland in the East; Nagaland and Karbi Anglong in the South; Sonitpur, Nagaon and Karbi Anglong in the West. The total area of Upper Assam is $21,742 \mathrm{sq} \mathrm{km}$. and total population is 7,692,728.

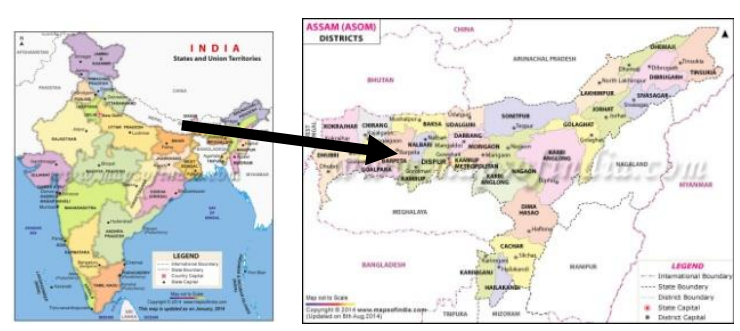

Figure 1:1: Showing map of India and Assam

Upper Assam is located in great Brahmaputra Valley. Brahmaputra river passes through 3countries. Its total length within Tibet of China is about $1700 \mathrm{~km}$, in India it runs for 920 km (Arunachal Pradesh $280 \mathrm{~km}$ and Assam 640km) and in Bangladesh its independent length is $260 \mathrm{~km}$. The entire basin of the Brahmaputra inside and outside India is about $580,000 \mathrm{~km} 2$.

There have total 7 district in Upper Assam according to 2011 census. For this Paper, Jorhat District is represent as Centre. Though it, all ASCT Bus and Traveller Service can be studies in other District of Upper Assam.

Published By:

Blue Eyes Intelligence Engineering \& Sciences Publication

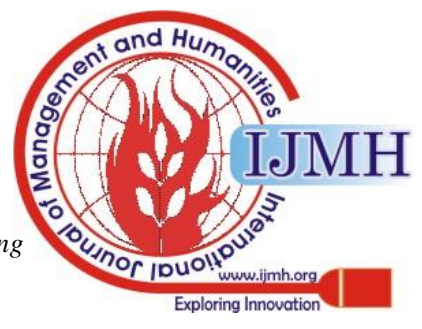




\section{ANALYSIS}

Transport Network analysis is a link or connection between two or many places. In India, road transport system are biggest transport than the other mode of transport. In this paper, there have to study only the transport netwok analysis of Upper Assam in comparision of two services. One in ASTC Bus Service which is run by the government of Assam and other are Traveller Services which are run by the Private or Public people.

\section{A. Astc Bus Service:}

Under ASTC Bus Services, there have seen only 11 buses which run in Upper Assam from the district of Jorhat to other districts in every day. On average 42-52 seats are available in ASTC Bus Service. In the below, there have given the distribution of buses in different district from the Centre.

Table1:1: Numbers of ASTC Bus Service in Upper

Assam (Collected from ASTC office Counter; on 12.03.2020 at 9.30am)

\begin{tabular}{|c|c|}
\hline DISTRICTS & $\begin{array}{c}\text { No.Of ASTC BUS } \\
\text { SERVICE (per day) }\end{array}$ \\
\hline Jorhat to Tinsukia & 4 \\
\hline Jorhat to Dibrugarh & 2 \\
\hline Jorhat to Sibsagarh & 1 \\
\hline Jorhat to Golaghat & 1 \\
\hline Jorhat to Dhemaji & 1 \\
\hline Jorhat to Lakhimpur & 2 \\
\hline
\end{tabular}

With the help of above date, there have to prepared a flowline cartogram., through which it is clearly analysis that the services in the road are less in compared to roads. It is almost 2 bus (on average) run in this areas. Therefore, Passengers face difficulties to travel in Bus.

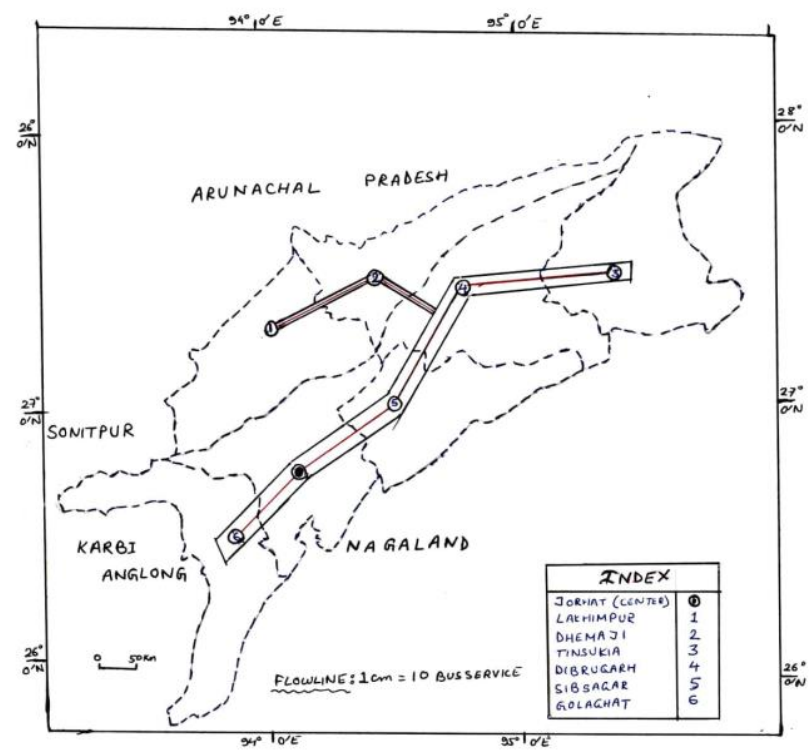

Figure 1:2: Showing map of Flowline Cartogram of ASTC Bus Service in Upper Assam

\section{B. Traveller Services:}

Under Traveller Service, there have seen total 90 Travelar Service runs in Upper Assam in every day.But, it is not fix to run all the travelesr in every days. It is depend of passenger, time and situation. On average, there have 15-20 seats are available in Traveller Services .In the below, there have given the distribution of traveller in different district from the Centre
Table 1.2: Number of Traveller Services in Upper Assam (Collected from Travelar Office at Jorhat; on 12.03.2020 at $1.30 \mathrm{pm})$

\begin{tabular}{|c|c|}
\hline DISTRICT & $\begin{array}{c}\text { NO. OF TRAVELLER } \\
\text { SERVICE (per day) }\end{array}$ \\
\hline Jorhat to Tinsukia & 12 \\
\hline Jorhat to Dibrugarh & 16 \\
\hline Jorhat to Sibsagarh & 18 \\
\hline Jorhat to Golaghat & 22 \\
\hline Jorhat to Dhemaji & 12 \\
\hline Jorhat to Lakhimpiur & 10 \\
\hline
\end{tabular}

With the help of above date, there have prepared a flowline cartogram to distinctly analysis the present scenario of traveler service in upper Assam. From the study ,it is clear that traveler service plays the important role in transport system.

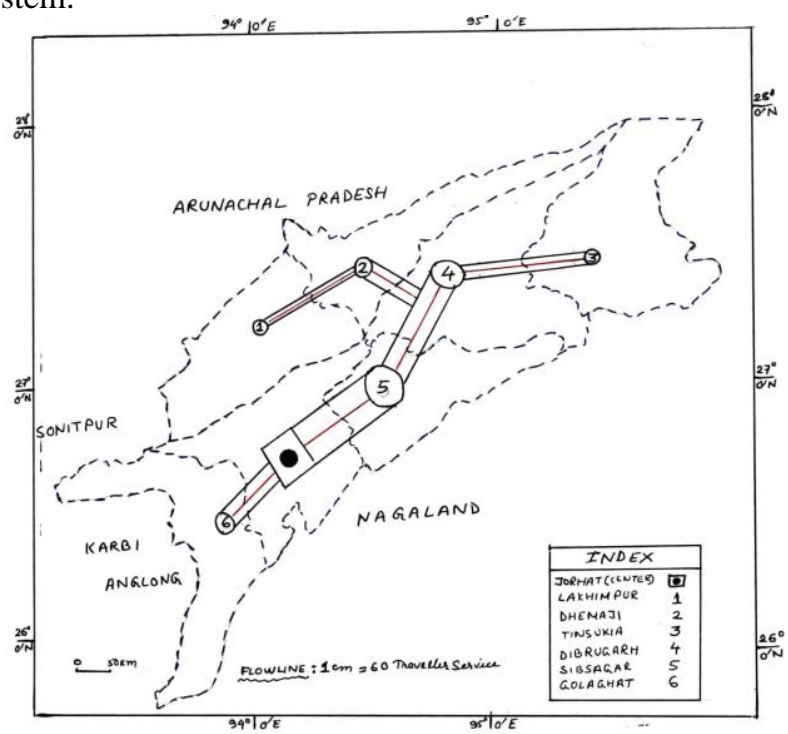

Figure 1:3: Showing map of Flowline Cartogram of Traveller Services in Upper Assam

\section{Comparition Betweeb Both The Services:}

- $\quad$ ASTC Bus service provide less number of services than the travelar services in a day.

- Rate of travelling in traveler service were increases and ASTC bus service were decreses day by day in Upper Assam.

- $\quad$ There have no provision to travel ASTC Bus Service in short distance.But in Traveller Service, it provide incresesing numbers of cars day by day.

- In ASTC bus Service, there have high time consuming. But in case of Traveller Serviices, it is a short duration. Because passenger are fix to their destination in a particular area.

- $\quad$ ASTC bus Service were more comfort than the Traveller Service.

- $\quad$ Maintainance of ASTC Bus Service are very very less than the other services.

- Very conjusted to travel in Travellers.

\section{D.Factors Face By Both Services:}

- Passengers Demand: People always try to reached their destination very fast. Due to it, people want to go with traveler service.

$$
\text { and } \mathrm{Hum}
$$

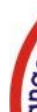


- $\quad$ Time : Time plays important factors in transport.Less duration always preferred by people.

- Distance: For travelling a long distance, people always prefer comfortable Bus services.

- Good Environment: Very net and clean environmental condition can be required by the passenger.

- Comfortness of travel: People want comfortness in each and every Journey. They always try to well maintain and good seating arrangement in their journey.

\section{E. Problems Face By Both Services:}

- Quantities Varies: There have only 11 ASCT Bus Service and 90 travelar services in the people of upper Assam.

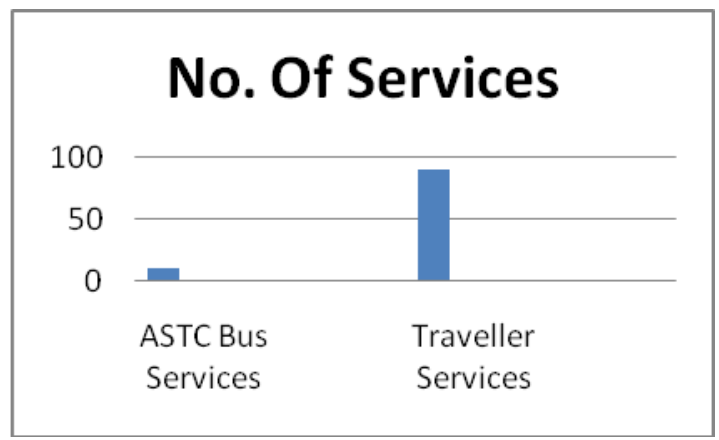

Fig 1:4: showing the number of both the services in a day

- Fare: Service fare play important role in selection of a journey. Compare to ASTC bus service, high rate of fare can be pay in Traveler Services.

- Maintainance : ASTC Bus cannot maintain comfortness in their services. They will not modify or to maintain all accessories in proper way. Due to it, People can't want to go with their services.

- Comfortness: In case of traveler service, People can be carry like a Vip. In a small space , owner carry large number of people .Sometime it feel safocation while travelling.

- $\quad$ Setting of Luggage: There have a very small area to setting or arrange the passengers' luggages. If People increase than luggage also increases.

- Government Awarness: There have less no of important by the government in the transport sectors. In other country, people try to go with government transport service. But in Upper Assam, we saw a different images.

\section{CONCLUSION}

Transport Network Analysis play a tremendous role in our transport system. Link of Node and Arc are essential in joining a places. There should be necessary to fix a number of car which travel in a particular areas. Because, sometimes road are broken or damage, if we travel in their for a long time than modification of a roads can not be take place. So , in a sufficient time, government and public authorities try to modify their road in time to time.

In this paper, there have to discuss about the transport network analysis in comparision to ASTC Bus Service and Traveller Service in Upper Assam District of State of Assam. In my study, there have seen that number of public and private sector services increases than the Government services. I hope in future there have to seen more government transport facilities not only in Upper Assam but entire State of India.

\section{REFERENCE}

1. S.K. Baruah; "Assam Year Book 2017”, Published by Jyoti Prakashan Guwahati ; $10^{\text {th }}$ edition January, 2017; p.p: 87,91 and 132

2. M.G.H.Bell, Yasunori Lida; "Transport Network Analysis" ; April 1997; p.p: 226

\section{AUTHORS PROFILE}

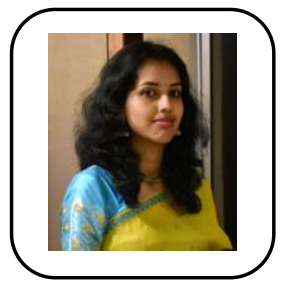

Neelakshi Borthakur, (M.A., B.Mus, B.Ed., PGDCA) is a Assistant Professor in the Department of Geography in D.C.B. Girls College Jorhat, Assam. She is a passionate academician with 7 years of experiences in the field of Geography. Author interest to work in the field of Geography with specialized in Cartograph, GIS, Rural Development and Musical Geography. She always try to collect new and innovative concept in her research works. She also interest to work in the field of barning issues related with the environments. At Present, she has presented and published many research paper in various National and International Journals and Conferences.

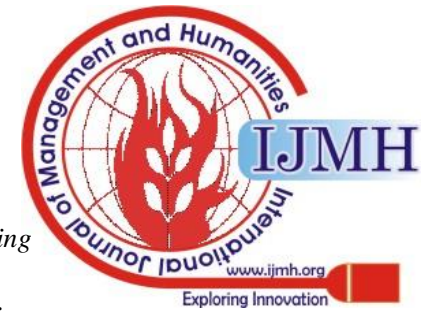

